\title{
Personal Hygiene Of Workers In Waste Disposal Site Ponorogo Regency, East Java, Indonesia
}

\author{
Rindang Diannita ${ }^{*}$, Dikri Amarulloh ${ }^{2}$, Eka Rosanti ${ }^{3}$, \\ Muhammad Rifki Taufik ${ }^{4}$ \\ 1,3,4 Lecturer Occupational Safety and Health Department, \\ Faculty of Health Science, Universitas Darussalam Gontor, \\ Siman Street, Ponorogo, East Java, Indonesia. \\ ${ }^{2}$ Student Occupational Safety and Health Department, Faculty of \\ Health Science, Universitas Darussalam Gontor, Siman Street, \\ Ponorogo, East Java, Indonesia \\ *Corresponding author: \\ Email: rindangdiannita@unida.gontor.ac.id
}

\begin{abstract}
.
Personal hygiene is useful in maintaining the health of workers. However, Personal Hygiene is considered less important for workers due to the knowledge and attitudes of workers' personal hygiene. One's knowledge will have a positive and negative impact on one's actions. Garbage becomes a source of various diseases if not managed properly. The purpose of this study was to analyze the personal hygiene behavior of waste disposal workers and the factors that influence behavior. The research method is qualitative with a descriptive approach, with a total of 10 informants. Data collection techniques were carried out by in-depth interviews and direct observation. The results of the research on the personal hygiene behavior of workers are very important, knowledge of workers regarding personal hygiene and occupational safety and health is very necessary, by paying more attention to and improving personal hygiene, by maintaining hand hygiene, feet, nails, hair hygiene and maintaining skin hygiene on a regular basis. completing sanitation facilities, increasing management support in the form of occupational safety and health supervision. Managers are expected to be able to apply Occupational Health and Safety and apply personal hygiene behavior in particular.
\end{abstract}

Keywords: Personal Hygiene, Waste Disposal Site, Occupational Safety and Health

\section{INTRODUCTION}

Management of waste with important implications for human health and wellbeing, environmental preservation, sustainability and economy is a demanding and challenging undertaking in all European countries. Comprehensive legal frameworks, mainly developed on the basis of environmental criteria, exist that regulate waste management. Compliance with these regulations has resulted in significant progress; however concerns remain as to the possible health impacts of waste circulation, management and disposal, especially in connection with informal practices and obsolete technologies [1] A health is greatly influenced by the natural environment and social environment. So that each individual must strive for every aspect that exists in the environment and maintain health for the integrity of a healthy life free from disease 
[2] More interdisciplinary research can improve levels of knowledge about personal hygiene on risks to human health of waste disposal in waste sites in especially [3] Waste Disposal Sites (WDS) have the potential to disrupt the health of scavengers and their managers, because in these areas there are piles of garbage that have the potential to breed viruses and bacteria and can also have a negative impact on health [4] Waste that accumulates can cause various kinds of infectious and non-communicable diseases and can also be in the form of fire, poisoning and others.

Diseases transmitted by vectors in the form of bacteria, fungi, worms and chemicals can be increased through waste [5]The available scientific evidence on the waste-related health effects is not conclusive, but suggests the possible occurrence of serious adverse effects, including mortality, cancer, reproductive health, and milder effects affecting well-being [1] Environmental and health problems due to waste and waste are also increasing. The quality of river water in Indonesia is generally in a heavily polluted status. In 2018, 25.1 percent of villages experienced water pollution, and around 2.7 percent of villages were contaminated with soil. Waste also contributes to flood events which continue to increase from year to year, in 2016 and 2017 as many as 1,805 floods occurred in Indonesia and caused 433 fatalities. An alarming condition is the case fatality rate / CFR due to extraordinary diarrhea events in 2016 of 3.04 percent, even though the CFR is expected to be less than 1 percent [6] Waste Disposal Site (WDS) in Ponorogo Regency, some workers were found to be lacking in personal hygiene behavior such as workers washing their hands with soap but in practice they were still not correct, and lacked the use of personal protective equipment.

Lack of knowledge of workers about the function of shampoo in maintaining health, worker attitudes regarding hand, foot and nail hygiene consider it important but in practice it is still not correct so that in their actions they still carry out hand washing steps, sanitation facilities at the Ponorogo Waste Disposal Site are under standards, there is no work supervision based on occupational safety and health at the Ponorogo Waste Disposal Site which is support driven by the manager.From this background, work related to waste has potential health hazards that are important enough to be considered, which can affect the health of workers. The application of personal hygiene needs to be part of every job in Waste Disposal Site Ponorogo to maintain the health of workers and efforts to prevent exposure to potential diseases that exist in the work environment. Therefore, further research is needed on personal hygiene behavior in the Waste Disposal Site in Ponorogo Regency.

\section{METHODS}

Types of research this is a descriptive study with qualitative data and analysis. The research location is in the Ponorogo Waste Disposal Site. The population and sample used the entire population of the Ponorogo Waste Disposal Site workers, which 
amounted to 10 informants. Data collection uses primary data (interviews) and observations, as well as secondary data (labor data) at the Waste Disposal Site (WDS). The validity of the data in this study used triangulation techniques. The triangulation technique according to Sugiyono that the technique of triangulation is a technique of collecting data and sources that have been there is. Research that uses data collection by triangulation, the researchers collect data which also tests credibility data, by checking the credibility of data collection and with various data sources [7]For technical triangulation, in this research using Head of WDS, Manager of WDS, and Workers.

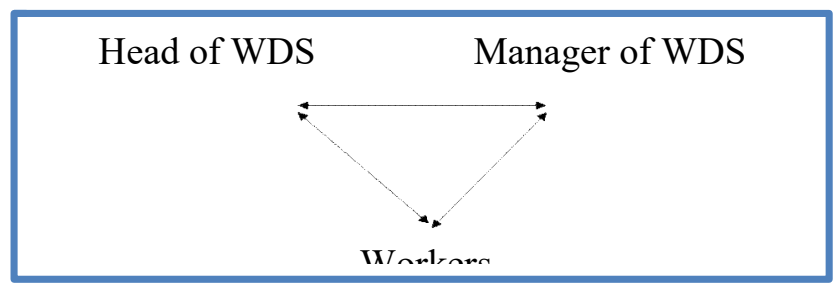

Fig 1. Triangulation of Technical Sources

(Source: Primary Data, 2021)

For Technical Source Triangulation, in this research using interviews, observation and documentation.

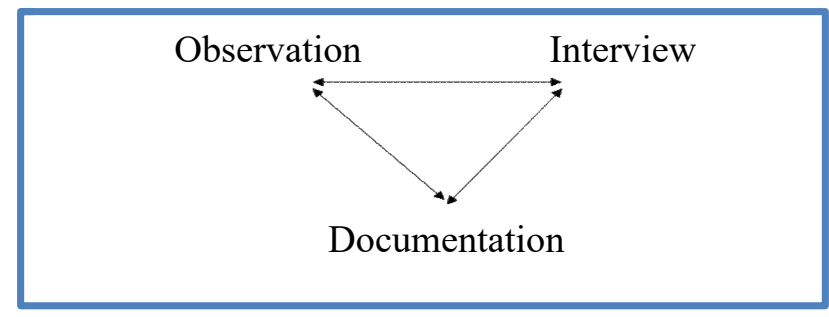

Fig 2. Technical Source Triangulation

(Source: Primary Data, 2021)

\section{RESULT AND DISCUSSION}

The Ponorogo Waste Disposal Site manages the waste in Ponorogo. The system used in managing waste is Preprocessing which is the initial stage of separating waste, knowing the type of incoming waste. Waste sorting was done manually by workers to separate waste by type. Waste management by enumeration to reduce waste particles such as plastic cup waste, sorting waste based on the density value of waste and processing organic waste into compost and fish pellets but it is no longer running.

\section{Characteristics of Informants}

Characteristics of informants in the study of Personal Hygiene Behavior Analysis of Workers in Ponorogo Waste Disposal Sites (WDS) include: 


\section{Age}

Table 1. Age of Workers in WDS

\begin{tabular}{rcc}
\hline Age & Total & Precentage (\%) \\
\hline 26-45 years old & 3 & $30 \%$ \\
46-65 years old & 7 & $70 \%$ \\
\hline Total Informan & 10 & $100 \%$ \\
\hline
\end{tabular}

Source: Secondary Data, 2021

Based on table 1, it can be seen that the informants aged 26-45 years were 3 people $(30 \%)$ while those aged 46-65 years were 7 people $(70 \%)$. According to Apriyanti (2018), the age of adults is between 26-45 years and the age of the elderly is between 46-65 years

\section{Gender}

Table 2. Gender of Workers in WDS

\begin{tabular}{lcc}
\multicolumn{1}{c}{ Gender } & Total & Precentage (\%) \\
\hline Perempuan & 10 & $100 \%$ \\
Laki-laki & - & - \\
\hline Total Informan & 10 & $100 \%$ \\
\hline
\end{tabular}

Source: Secondary Data, 2021

Based on table 2, it can be seen that all informants are female as many as 10 people, the percentage is $(100 \%)$.

\section{Education}

Table 3. Education of Workers in WDS

\begin{tabular}{lcc}
\hline Gender & Total & Precentage (\%) \\
\hline Primary School & 3 & $30 \%$ \\
Junior High School & 6 & $60 \%$ \\
High School & 1 & $20 \%$ \\
\hline Total Informan & 10 & $100 \%$ \\
\hline
\end{tabular}

Source: Secondary Data, 2021

Based on table 3, it can be seen that most of the informants have a junior high school education level (Junior High School) as many as 6 people (60\%).Based on Lawrence Green's theory that behavior is influenced by three factors, namely (1) predisposing factors; age, occupation, education, knowledge and attitude (2) enabling factors; distance to health facilities (3) booster factor; family and community support [8]. In this research predisposing factors, enabling factors, booster factor:

\section{(1) Predisposing Factors}

\section{a. Knowledge}

The results of interviews with triangulated informants regarding the knowledge of the importance of keeping hands, feet and nails clean, All informants knew that keeping hands, feet and nails clean is important and said dirty hands, feet and nails can also cause various diseases such as diarrhea, itching itching and so on.Regarding the knowledge of hair hygiene, it was obtained from the interview of informants that they knew that maintaining hair cleanliness was important. Informants do shampooing to 
relieve itching, keep hair clean, shampooing can also relieve itching on the head and keep hair from damage and keep it clean.Knowledge of triangulation informants in maintaining skin cleanliness knowing that bathing is important for maintaining a healthy body. Informants said that bathing is useful for keeping the body clean, eliminating waste, keeping the skin clean, bathing also preventing itching on the skin and preventing the skin from getting sick easily.

\section{b. Attitude}

The results of interviews with triangulated informants regarding the time to wash hands, feet and nails showed that all of the informants handled hand and foot washing after work. Several informants responded that washing hands and feet is necessary after work and wanting to eat, before eating washing feet before bathing, as often as possible during work. Triangulation information may be about the attitude in nails obtained that informing about nail matters once a week, once or once, once or once, once once and of course nails was done for once a week. When the nails started to get long and dirty, all the informants responded with discomfort so that they kept the nails clean.The attitude given by the triangulation informants regarding the time of shampooing their hair was found that the informant responded to shampooing at least 2 times a week, usually the informant did the shampooing every 2 days while working at the Waste Disposal Sites (WDS) and shampooing every day to keep the hair clean.

Meanwhile, regarding the attitude of how much to bathe in a day, it was found that the informant responded that while working at the Waste Disposal Sites (WDS) the showered 3 times a day. While the results of interviews regarding work lending and borrowing, it was found that the information on borrowed clothes lends clothes that are permitted during new and clean work, there are also those who do not know and do not respond to borrowing and borrowing clothes.

\section{c. Action}

The results of interviews with triangulated informants on how to wash hands and feet showed that all informants washed their hands with soap, how to intersect their fingers and wash them with soap. As for nail cutting care, all of the informants cut and took care of their nails once a week or on Fridays which coincided with work holidays.Regarding the amount of shampooing in a week, it was found that the informants wash their hair at least 2 times a week and they wash their hair every day when there is a lot of garbage piling up in the Waste Disposal Sites (WDS). As for how to wash hair, all informants wash their hair using shampoo and running water.Informants wear work clothes from home to work or Waste Disposal Sites (WDS). Meanwhile, regarding changing work clothes, it was found that triangulation informants changed work clothes with ordinary clothes when they arrived home.

\section{(2) Supporting Factors}

The distribution of sanitation facilities in Waste Disposal Sites (WDS) Ponorogo in this study can be seen in the table below. 
Table 4. Distribution of Sanitation Facilities to Respondents at WDS Ponorogo

\begin{tabular}{|c|c|c|c|c|}
\hline \multirow{2}{*}{ No } & \multirow{2}{*}{ Observation Object } & \multicolumn{2}{|c|}{ Category } & \multirow{2}{*}{ Informatior } \\
\hline & & Yes & No & \\
\hline 1 & There are Sanitation Facilities. Toilet & $\sqrt{ }$ & & - \\
\hline 2 & Separate between women and men. & & $\sqrt{ }$ & - \\
\hline 3 & Clean water is available. & $\sqrt{ }$ & & \\
\hline 4 & Clean toilets. & & $\sqrt{ }$ & - \\
\hline 5 & There is a bathroom. & $\sqrt{ }$ & & - \\
\hline 6 & There is a latrine. & $\sqrt{ }$ & & - \\
\hline 7 & There is a warning. & & $\sqrt{ }$ & - \\
\hline 8 & There is a sink. & & $\sqrt{ }$ & - \\
\hline 9 & $\begin{array}{l}\text { There are more than } 1 \text { bathroom, and } 1 \\
\text { toilet }\end{array}$ & & $\sqrt{ }$ & $\begin{array}{l}\text { More } 1 \\
\text { bathroom } \\
\text { available }\end{array}$ \\
\hline Tota & & 4 & 5 & - \\
\hline
\end{tabular}

Source: Primary Data, 2021

Based on table 4, it is known that, there are sanitation facilities (toilet) in Waste Disposal Sites (WDS), there are no separate toilets between women and men, clean water is available, there are bathrooms, there are latrines, but there are no toilets, sinks, the number of bathrooms exceeds the comparison with the number of toilets. worker. And this is documentations in Waste Disposal Sites (WDS):

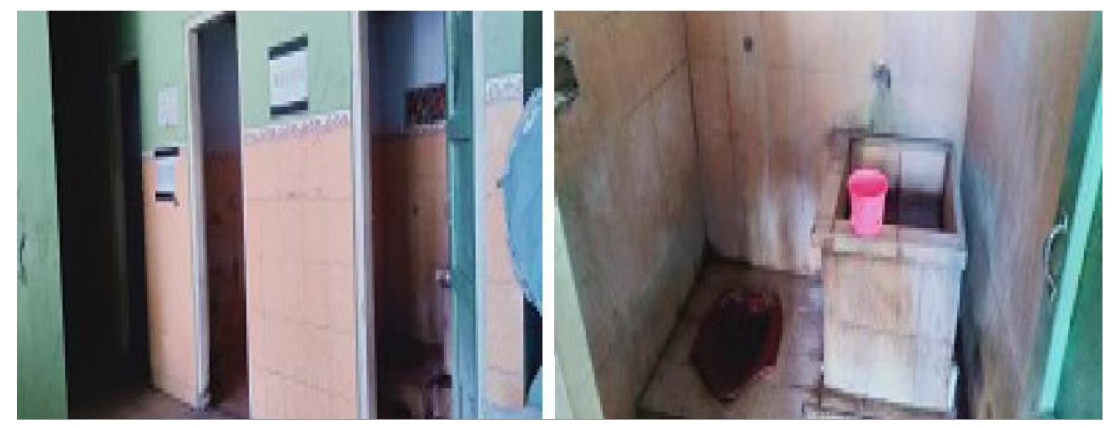

Fig 3. Waste Disposal Sites (WDS) Toilet

(Source: Primary Data, 2021)

\section{(3) Reinforcing Factor}

The reinforcing factor in this research is the support from the. Based on the results of interviews from the head of the Waste Disposal Sites (WDS) and manager, it was found that since the beginning of the establishment, the Waste Disposal Sites (WDS) did not have work procedures based on occupational safety and health that support OSH supervision so that the manager's supervision of workers regarding personal hygiene was less because it focused more on monitoring waste management work. every activity. Whereas the support from managers is in the form of OSH based supervision as a driver in the personal hygiene behavior of workers at Waste Disposal Sites (WDS). 


\section{Discussion}

In this research Overview of Predisposing Factors from some factors such as Knowledge, Attitude, Action:

\section{Knowledge}

All triangulation informants said it was important to keep hands, feet and nails clean and vice versa about dirty hands, feet and nails that can cause disease. Keeping hands, feet and nails clean is important in maintaining health and is part of personal hygiene. According to informants 1, 3, 9 and 10, dirty hands, feet and nails can also cause various diseases such as diarrhea, itching and so on. This is in accordance with the statement by Apriyanti that dirty hands and feet can carry germs that can disrupt a person's health such as germs and worm eggs that can be swallowed when hands and nails are dirty [9]. Washing hands with soap can eliminate a large number of viruses and bacteria that cause various diseases, especially diseases that attack the gastrointestinal tract such as diarrhea and respiratory tract infections [5].All triangulation informants know that keeping hair clean is important. Informants 1 and 2 wash their hair to relieve itching. Informants 3,7,8,10 said that shampooing can keep hair clean.

According to Informants 4 and 5, apart from keeping the hair clean, shampooing can also relieve itching in the head. Informant 9 said shampooing can keep hair from damage and keep it clean. This is not in line with Faridawati's [5]statement that washing hair using shampoo and regularly can treat hair and prevent certain infections or diseases. Keeping the skin clean is necessary in maintaining healthy skin and is part of personal hygiene. All triangulation informants knew that bathing in maintaining skin cleanliness was important for maintaining a healthy body. Informants $3,5,6,7,8$ and 9 said that bathing is useful for maintaining body hygiene, informants 1 and 2 think that bathing can eliminate waste. informant 4 said that apart from keeping the skin clean, bathing also prevents itching on the skin. Informant 9 said that bathing prevents the skin from getting sick easily. In practice, all informants showered 3 times a day while working at the Waste Disposal Sites (WDS), namely in the morning before leaving for work, in the afternoon during breaks and in the afternoon after returning from work from the Waste Disposal Sites (WDS).Based on the discussion of the knowledge of all triangulation informants above regarding personal hygiene knowledge in the form of knowledge of hand, foot and nail hygiene, knowledge of hair hygiene and skin hygiene formed at the application level.

In Lawrence Green's theory of application (applicaton), it means the ability to use the material that has been studied in actual situations or conditions [10]This is in line with that bathing can keep the body clean, healthy and odor-free, in maintaining healthy skin, healthy habits must be maintained frequently, such as bathing with soap regularly at least 2 times a day [9] The results of the study indicate that the knowledge of Waste Disposal Sites (WDS) workers regarding personal hygiene has a role in 
influencing behavior. This is in line with Yuda's research there is a significant relationship between knowledge and personal hygiene behavior of the community. This means that if people's knowledge is getting better, their personal hygiene behavior will also be getting better [11] In another study, namely the results of research, showed that there was an influence of knowledge on occupational safety and health on the incidence of work accidents (significant value $=0.002<0.05$ ), there was an influence of behavior on the incidence of work accidents (significant value $=0.004<0,05$ ) [12]

\section{Attitude}

All triangulation informants said that washing hands and feet needs to be done after work. Informants 1, 2, 4, 5, 7 and 8 responded that washing hands and feet is necessary after work and wanting to eat. Informant 3 washes hands before eating while washing feet before bathing. Informants 6, 9 and 10 responded that washing hands and feet needs to be done as often as possible during work. It is necessary to cut nails once a week, like the attitude of informants 1,2,3 and 7. Informant 4 responded that cutting nails once or twice a week. Informants 5 and 10 responded that cutting nails is not necessarily done once a week. Informants 6,8 and 9 responded that cutting nails was done as often as possible. When the nails started to get long and dirty, all the informants responded with discomfort so they kept their nails clean.Apriyanti's research suggests washing hands and feet to maintain cleanliness should be done after going to the toilet, before making or serving food or food and touching garbage, cutting nails regularly, washing feet before going to bed and cleaning the surrounding environment [9], and it is important to wash hands, namely before eating and after eating, after defecating and urinating, before holding the baby, before preparing food and after coughing or sneezing that contaminates the hands [5]Shampoo in a week which is part of keeping the hair clean.

it is known that the attitude of informants 3, 4 and 5 doing shampooing in a week as much as 2 times, informants $1,2,6,7,8$, and 9 responded that shampooing was done once every 2 days while working at Waste Disposal Sites (WDS). While informant 10 responded that shampooing every day in maintaining the cleanliness of the hair. The informant responded in maintaining skin cleanliness that while working at the Waste Disposal Sites (WDS), he took a shower 3 times a day. In responding to borrowing and borrowing work clothes, informants $1,3,8,9,10$ thought that borrowing and borrowing work clothes was allowed as long as the work clothes were new and clean. Informant 2 responds to not knowing in terms of borrowing and borrowing work clothes. 4, 5, 6 and 7 do not address this.This is in accordance with Hidayat's expression in that there are several habits to maintain skin cleanliness such as bathing using soap at least 2 times a day, using clean and neat clothes and changing when they are dirty and wet, avoiding the use of clothes together, the same and Avoid wearing damp or wet clothing [9]. 
Based on the discussion of the knowledge of all triangulation informants above regarding personal hygiene attitudes in the form of hand, foot and nail hygiene attitudes are formed at the level of acceptance in Lawrence Green's theory receiving means that people who want and pay attention to the given stimulus. While the attitude of hair hygiene and skin hygiene is formed at the level of responding in Lawrence Green's theory of responding (responding), meaning that workers provide answers when asked, do and complete the tasks given according to personal hygiene [10]The results of the study indicate that the knowledge of Waste Disposal Sites (WDS) workers about personal hygiene has a role to influence behavior, this is in accordance with Mahendra that the attitude of the main informant above supports behavior even though there is a lack of attitude, namely the attitude of hand, foot and nail hygiene [13]

\section{Action}

All triangulation informants stated that washing hands, feet and taking care of nails is important in caring for and maintaining personal hygiene at work. In practice, informants $1,4,6,7,8$, and 9 washed their hands with soap. Informants 2, 3, 5 and 10 wash their hands by intervening their fingers and washing them with soap. All informants cut and partly took care of their nails once a week or on Fridays which coincided with work holidays. This is not in line as stated Setyanto in Diannita research, stating that proper hand washing is to first wet hands with running water and then rub soap evenly on hands, nails to elbows for at least 10-15 seconds, then rinse with water, then dry hands with a clean towel. or disposable wipes [10]. Washing hands using soap is one of the effective ways to prevent the spread of microorganisms, but some people in fact still do not know how to wash their hands properly [14] All triangulation informants wash their hair at least 2 times a week.

The researcher stated that the behavior of the informants in maintaining the cleanliness of their hair was good. Informants 4,5 and 7 wash their hair every day when there is a lot of garbage piling up in the Waste Disposal Sites (WDS). All informants wash their hair using shampoo and running water every time. This is in accordance with what was expressed by Faridawati that a person's health can be seen by the presence of good hair. To keep the hair clean, it takes several efforts such as washing your hair at least twice a week and washing your hair using shampoo [5]Keeping the skin clean regarding work clothes, it was found that all informants wore work clothes from home to work or Waste Disposal Sites (WDS). Change work clothes with normal clothes when you get home and change other work clothes the next day. This is in accordance with Setyanto in Diannita research that changing clothes regularly is one way to keep the skin clean and in changing clothes at least once a day.

Based on the discussion of all triangulation informants above regarding personal hygiene attitudes in the form of hand, foot and nail hygiene attitudes are formed at the level of perception in Lawrence Green's theory of perception 
(perception), a person's first action will be to recognize and choose various objects in a relationship that will be related to the action to be taken. did. Meanwhile, the attitude of hair hygiene and skin hygiene is formed at the level of the mechanism in Lawrence Green's theory of the mechanism (mechanism), when the worker's actions have begun to be carried out continuously in carrying out personal hygiene [10]. The results of the study indicate that the personal hygiene actions of Waste Disposal Sites (WDS) workers support personal hygiene behavior where this action is influenced by knowledge and attitudes such as hand, foot and nail hygiene which do not affect their actions. This is in line with Rianda that the lack of knowledge and attitudes of scavengers about personal hygiene results in poor actions as well [15]
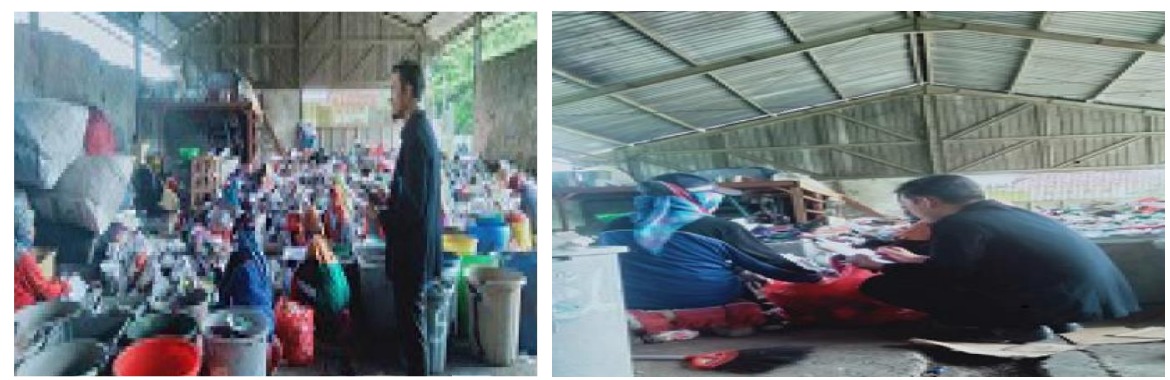

Fig 4. Waste Disposal Sites (WDS) Location in Ponorogo Regency (Source: Primary Data, 2021)

\section{Overview of supporting factors}

Based on the results of observations of sanitation facilities at Waste Disposal Sites (WDS) there are 4 answers, 4 answers "yes" and 5 answers "no". So it can be seen that the sanitation facilities at the Waste Disposal Sites (WDS) are in the category of not meeting the requirements, because there are 5 "no" answers to the assessment of sanitation facilities.Based on the Decree of the Minister of Health of the Republic of Indonesia NO. 1405 of 2002 concerning health requirements for office and industrial work environment facilities, the work environment must have sanitation facilities. One of the sanitation facilities in the work environment is the toilet. The toilet requirements are separate for women and men and there is a sink, latrine and toilet.According to Lawrence Green, the availability of supporting infrastructure is a supporting factor for a person to perform a behavior [16]In this study, the lack of availability of sanitation facilities was related to the personal hygiene behavior of Waste Disposal Sites (WDS) workers. Thus the supporting factors are less able to support personal hygiene behavior. In addition, to support the formation of good actions, it is necessary to have facilities in the form of a hand washing place. Installation of banners can also be done, for example, prioritizing safety and continuing to improve personal hygiene [15]

\section{Overview of Reinforcing Factors}

Management support at Waste Disposal Sites (WDS) in the form of supervision in work to achieve work targets. Supervision in carrying out work in order 
to achieve a goal is very important to do. If a job is not followed by supervision, it cannot look good. If the work is not going in line with the plan, then the goal of the work cannot be achieved [17]Based on the results of interviews and direct observations, it was found that there was no supervision based on Occupational Health and Safety (OSH), especially personal hygiene which was an effort to maintain safe and healthy work at Waste Disposal Sites (WDS). Supervision aims to ensure that the activities carried out are carried out according to plan and some organic functions, supervision is one of the absolute tasks carried out by all parties at the managerial level and directly controls the activities carried out by operational officers. Lawrence Green explained that manager support is a reinforcing factor that influences work behavior. However, in this study the management support did not support personal hygiene behavior. Thus the reinforcing factor at Waste Disposal Sites (WDS) in the form of support from managers in the form of OSH supervision does not support the personal hygiene behavior of Waste Disposal Sites (WDS) workers [18]

\section{Personal Hygiene Behavior Analysis}

From the results of observations and triangulation interviews regarding personal hygiene behavior, it is known that the personal hygiene knowledge of informants at Ponorogo Waste Disposal Sites (WDS) regarding the importance of maintaining hand, foot and nail hygiene, hair hygiene and skin hygiene have a role in shaping the personal hygiene behavior of workers. This is in accordance with Yuda there is a significant relationship between knowledge and personal hygiene behavior of the community. This means that if people's knowledge is getting better, their personal hygiene behavior will also be getting better [11]According to Kurniawidjaja, there are three main reasons agencies need to implement occupational safety and health, namely because the obligations of the government contained in laws, regulations, and ministerial decisions, are Human Rights (HAM), as well as for consideration in terms of economic losses/benefits [18].

The personal hygiene attitude of triangulation informants regarding hand, foot and nail hygiene that is not appropriate so that it affects the actions of informants who do it such as how to wash hands with steps that are not correct while the attitude of hair hygiene and skin hygiene is appropriate to provide a role in informants acting in maintaining hair cleanliness and hygiene skin.Attitudes and actions have a role in influencing one's behavior as well as knowledge which is the domain of the behavior itself [19]. In this study, the lack of availability of sanitation facilities was related to the personal hygiene behavior of Waste Disposal Sites (WDS) workers. Supporting factors are less able to support personal hygiene behavior. According to Lawrence Green, the availability of supporting infrastructure is a supporting factor for a person to perform a behavior [20]Support from Waste Disposal Sites (WDS) managers in maintaining worker performance is by monitoring $\mathrm{K} 3$ in the workplace. 
However, based on the results of interviews and direct observations, it was found that there was no supervision based on Occupational Safety and Health (OSH), especially personal hygiene which was an effort to maintain safe and healthy work at Waste Disposal Sites (WDS).Supervision of occupational safety and health that does not affect the behavior of workers so that changes made by workers are only temporary while under the supervision of the manager and if not under supervision, they will return to their old behavior [13]. All aspects of occupational safety and health, and it is recommended that workers comply with standard operating procedures for occupational safety and health [19]From the results of interviews and observations regarding predisposing factors, knowledge is appropriate, attitudes and behavior are not appropriate in the hygiene section of fingernails and nails, supporting factors in the form of inadequate sanitation facilities and reinforcing factors in the form of support from Waste Disposal Sites (WDS) managers lacking in OSH supervision at Waste Disposal Sites (WDS) so that the personal hygiene behavior of workers is still not good, based on the Decree of the Minister of Health of the Republic of Indonesia [21]

\section{CONCLUSION}

From the results of research on the analysis of personal hygiene behavior of workers at the Waste Disposal Site (WDS) in Ponorogo, it can be concluded that: (1) Knowledge of informants in this study at the application level in Lawrence Green's theory can use the material that has been studied in actual situations or conditions and knowledge is in accordance with personal hygiene theory (2) Some of the informants responded that personal hygiene was appropriate, such as hair hygiene and skin hygiene, and was still not appropriate in responding to hand, foot and nail hygiene (3) The actions of the informants regarding the cleanliness of hands, feet and nails were not appropriate, while the actions of the informants in maintaining the cleanliness of the hair and skin were appropriate (4) Sanitation facilities at Waste Disposal Sites (WDS) fall into the category of not meeting the requirements based on the Decree of the Minister of Health of the Republic of Indonesia concerning health requirements for office and industrial work environment facilities, the work environment and these facilities are supporting factors that have a role in behavior (5) Personal hygiene behavior in landfills Waste Disposal Sites (WDS) is still not good, influenced by predisposing factors in the form of appropriate knowledge, attitudes and actions that are not appropriate in maintaining the cleanliness of hands, feet and nails. Supporting factors in the form of sanitation that is not yet standard and management support in supervising informants is lacking as a reinforcing factor.

\section{ACKNOWLEDGMENTS}

The authors are grateful to the Head of WDS, Manager of WDS, Workers, and Universitas Darussalam Gontor. 


\section{REFERENCES}

[1] World Health Organization (WHO), "Waste and Human Health," Who, no. November, p. 35, 2015, [Online]. Available:

http://www.euro.who.int/pubrequest\%0Ahttp://www.euro.who.int/_data/assets/pdf_fil e/0003/317226/Waste-human-health-Evidence-needs-mtg-report.pdf?ua=1.

[2] C. Anggraeni, "Hubungan Pengetahuan Sanitasi Dan Higiene Dengan Sikap Siswa Kelas X Smk Negeri 6 Yogyakarta Di Laboratorium Boga,” J. Chem. Inf. Model., vol. 53, no. 9, pp. 1689-1699, 2013.

[3] M. Vrijheid, "Health effects of residence near hazardous waste landfill sites: A review of epidemiologic literature," Environ. Health Perspect., vol. 108, no. SUPPL. 1, pp. 101-112, 2000, doi: 10.1289/ehp.00108s1101.

[4] I. S. Mustikawati, "Perilaku Personal Hygiene pada Pemulung di TPA," Forum Ilm. Vol., vol. 10, no. 1, pp. 27-35, 2013.

[5] Y. Faridawati, "Hubungan antara Personal Higiene dan Karakteristik individu dengan keluhan Gangguan kulit pada Pemulung (Laskar Mandiri) di Kelurahan Sumur Batu Kecamatan bantar Gebang," Fak. Kedokt. dan Ilmu Kesehat. Univ. Islam Negeri Syarif Hidayatullah, pp. 14-27, 2013.

[6] Badan Pusat Statistik, "Statistik Lingkungan Hidup Indonesia (SLHI) 2018," Badan Pus. Stat. Indones., pp. 1-43, 2018, doi: 3305001.

[7] Sugiyono, "Metode Penelitian Kuantitatif Kualitatif dan R\&D." 2017.

[8] A. A. K. N. Darmawan, "Faktor-Faktor yang Mempengaruhi Perilaku Kunjungan Masyarakat terhadap Pemanfaatan Pelayanan Posyandu di Desa Pemecutan Kelod Kecamatan Denpasar Barat,” J. Dunia Kesehat., vol. 5, no. 2, pp. 29-39, 2015.

[9] Ayu Aulia Aprianti, "Faktor-Faktor Yang Mempengaruhi Kejadian Scabies Pada Pemulung Di Tpa Desa Kaliabu Kecamatan Mejayan Kabupaten Madiun,” J. Bhakti

Husada Mulia Madiun, vol. 9, no. 1, pp. 1-11, 2018, [Online]. Available: http://dx.doi.org/10.1016/j.neuropsychologia.2015.07.010\%0Ahttp://dx.doi.org/10.1016 /j.visres.2014.07.001\%0Ahttps://doi.org/10.1016/j.humov.2018.08.006\%0Ahttp://www. ncbi.nlm.nih.gov/pubmed/24582474\%0Ahttps://doi.org/10.1016/j.gaitpost.2018.12.007 \%0Ahttps://doi.org/.

[10] R. Diannita, “Analisis Illumination Level Terhadap Kecelakaan Kerja Di Rumah Sakit XYZ Indonesia," vol. 5, no. 1, 2020.

[11] M. E. Yuda, Z. Dahlan, and H. Hasyim, “Analisis Personal Hygiene Masyarakat Sekitar Lokasi Pengelolaan Sampah Di Tempat Pemrosesan Akhir (Tpa) Kota Muara Enim an Analysis of the Personal Hygiene of the Community Living Around the Garbage Disposal Location in the Garbage Last Processing Locatio," J. Ilmu Kesehat. Masy., vol. 4, pp. 70-76, 2013.

[12] R. Diannita, I. Indasah, and S. Siyoto, "Analysis of Work Accidents Based on K3 Knowledge and Work Behavior at Muhammadiyah Hospital in Ponorogo," J. Qual.

Public Heal., vol. 3, no. 2, pp. 383-389, 2020, doi: 10.30994/jqph.v3i2.87.

[13] S. Radita Mahendra, Bina Kurniawan, "Faktor-Faktor Yang Berhubungan Dengan Perilaku Penggunaan Alat Pelindung Diri (Apd) Pada Pekerjaan Ketinggian Di Pt. X," J. Kesehat. Masy., vol. 3, no. 3, pp. 572-581, 2015.

[14] C. D. W. H. Sundari, I. W. Merta, and I. G. A. D. Sarihati, "Hubungan Faktor 
Predisposisi, Pemungkin, dan Penguat dengan Praktek Cuci Tangan serta Keberadaan Mikroorganisme pada Penjamah Makanan di Pantai Kedongan,” J. Skala Husada, vol. 11, no. 1, pp. 67-73, 2014.

[15] D. P. Rianda, "Pengetahuan Dan Tindakan Personal Hygiene Pemulung di TPA Ganet Tanjungpinang," J. Kesehat. Masy., vol. V, no. 2, pp. 162-166, 2014.

[16] R. Diannita, “Analisis Penerapan Sistem Informasi Pelayanan Pasien di Klinik UIN SUKA Yogyakarta," Cakra Buana Kesehat., vol. 1, no. 01, pp. 1-8, 2015.

[17] D. A. Arifah, A. M. Baidowi, R. A. A. Rahma, and S. M. Phuspa, "Hubungan Faktor Pengetahuan Dan Sikap Dengan Perilaku 5R Pekerja Pabrik Roti La-Tansa Gontor Ponorogo," J. Ind. Hyg. Occup. Heal., vol. 4, no. 2, pp. 1-8, 2020.

[18] R. Diannita, "Cakra Buana Kesehatan," Cakra Buana Kesehat., vol. I, no. September 2015, pp. 1-8, [Online]. Available: https://www.researchgate.net/profile/RindangDiannita/publication/350192492_ANALISIS_PENERAPAN_SISTEM_INFORMASI_ PELAYANAN_PASIEN_DI_KLINIK_UTAMA_UIN_SUNAN_KALIJAGA_HEALT H_CENTER/links/6055a88c458515e83458df25/ANALISIS-PENERAPAN-SISTEMINFORMASI-PELAYANAN-.

[19] A. A. Basri, R. A. A. R, and R. Diannita, "Relationship of Predisposing and Enabling Factors with Unsafe Action of Nurse in the Inpatient Unit I of Rsud Dr. Saiful Anwar Malang," Indian J. Public Heal. Res. Dev., 2020, doi: 10.37506/ijphrd.v11i11.11407.

[20] M. Y. Labib, A. A. Basri, E. Rosanti, and R. Diannita, "Stres Kerja Pada Perawat Di Instalasi Rawat Inap RSU Darmayu Ponorogo,” J. Kesehat. Manarang, vol. 6, no. 2, pp. 112-118, 2020.

[21] Kementerian Kesehatan Republik Indonesia, "Peraturan Menteri Pekerjaan Umum dan Perumahan Rakyat Nomor 03 PRT M Tahun 2013 Tenta Penyelenggaraan Prasarana dan Sarana Persampahan dalam Penanganan Sampah Rumah Tangga dan Sampah Sejenis Sampah Rumah Tangga," Menteri Kesehat. Republik Indones. Peratur. Menteri Kesehat. Republik Indones., vol. Nomor 65, no. 879, pp. 2004-2006, 2013. 